\title{
4. アイソザイムの集団遺伝学*
}

ヒトにおける酵素の多型形質

\section{佐 藤 千代子**}

二つ以上の対立遺伝子が集団中に存在し，頻度の低 い対立遺伝子も反復突然変異だけでは説明できないよ うな頻度の場合に，多型現象（polymorphism）と定義 している ${ }^{1)}$.このような頻度とは，少なくとも 0.01 以上 とされているので, 最も頻度の高い対立遺伝子の頻度 も0.99以下である. しかし, この数字は便宜的に定め られたものである.

ヒトの多型現象で最初に発見されたものは, Landsteinerによって1900年に発見された ABO 血液型の多 型現象であった. O. Smithiesが, 1955年にでんぶんゲ 儿電気泳動法 $(\mathrm{SGE})^{2)}$ と，それを用いて観察した七 トのハプトグロビンの多型現象を発表しで） 以来， SGE はヒトの集団遺伝学に急速に導入された. 集団調 查において, 最も入手し易い検体である血液中の蛋白 質, 酵素の分析が広く行われ, allelic isozymes (allozymes）に関する多くのデータが集積された. その後 SGEよりも短時間で検査が可能で, 分離能の優れたポ リアクリルアミド薄層ゲル電気泳動法, ポリアクリル アミド薄層等電点分離法 (PAGIEF)，ポリアクリル アミド薄層ゲル 2 次元電気泳動法が次々に導入された。 特に等電点分離法 (IEF) によって, SGEによる分析 では単一とされていたバンドが， 2 本のサブバンドに 分離され，それぞれが異なる対立遺伝子の産物である ことが明らかとなった蛋白質も $2 ， 3$ にとどまらなか った. 一方, 酵素の活性, 熱安定性の測定, および抗 体を用いた酵素蛋白質の定量等により，電気泳動的に は分離できないアイソザイムの検出も行われるように なり，七ト集団の不均一性がより広沉なものとして理 解されるようになった. 集団遺伝学, 遺伝生化学的に 興味ある酵素は多いが，本報では，血液中に存在し
SGEによって多くの集団で検査されている多型形質， および，量的変異形質で，多型またはそれに近い頻度 を示したものを紹介する，さらに，PAGIEFを用いて はじめて検出された PGM 1 のアロザイムと，その進 化の機構，および突然変異との関係について論じたい。

主要 3 人種のコーカソイド，ネグロイド，モンゴロ イドの何れの集団においても，SGEで多型の観察され る赤血球酵素には, 酸性ホスファターゼ ( $\mathrm{ACP} 1)$, ホスホグルコムターゼ-1 と-3（PGM 1 と PGM 3 ), エステラーゼ D (ESD), グルタミン酸-ピルビン酸卜 ランスアミナーゼ-1（GPT1），6-ホスホグルコン酸 デヒドロゲナーゼ（6 PGD），アデノシンデアミナー ゼ (ADA) が知られている ${ }^{4)}$ (Table 1$)$. 主要対立遺 伝子頻度に，人種によって差のある場合もあり，頻度 の低い多型性の対立遺伝子が観察されない集団もある. $A C P 1^{*} A$ と $A C P 1^{*} B, P G M 3^{*} 1$ と $P G M 3^{*} 2, E S D^{*} 1$ と $E S D^{*} 2$ は前者の例であり, $A C P 1^{*} C, A C P 1^{*} R$, $P G M 1^{*} 7, E S D^{*} 5, E S D^{*} 7$ は後者の例である.

特定の人種だけに共通な対立遺伝子は, 主要 3 人種 がそれぞれ分離してからの，比較的新しい時代に生じ た突然変異に由来するものと考えられ，七卜集団のマ 一カーとして利用される，その点では，特定の集団に おいてのみ多型である酵素の対立遺伝子も同様に利用 される、それらには，AK1*2(コーカソイド), GOT1*2 (モンゴロイド), $P E P A^{*} 2$ (ネグロイド), $P E P D^{*} 3$ (ネグロイド)，PGM 2*2(ネグロイド）等がある．蛋 白質をコードする遺伝子座の中で多型性遺伝子座の占 める割合は, 人種によって異なるが, 30-40\%とされて いる ${ }^{5}$. しかし，これらの值は，量的に多く存在し，基 質特異性の少ない酵素，蛋白質群から得られているの

\footnotetext{
* Isozymes in population genetics - Enzyme polymorphism in man -

** Chiyoko Satoh, 放射線影響研究所 (広島) 臨床検査部遺伝生化学.
} 
Table 1. Polymorphic red cell enzymes.

\begin{tabular}{llccc}
\hline \hline Enzyme & Alleles & Caucasoids & Negroids & Mongoloids \\
\hline ACP1 & $A C P 1^{*} A$ & 0.373 & 0.14 & 0.197 \\
& $A C P 1^{*} B$ & 0.571 & 0.84 & 0.803 \\
& $A C P 1^{*} C$ & 0.057 & - & - \\
PGM1 & $A C P 1^{*} R$ & - & 0.02 & - \\
& $P G M 1^{*} 1$ & 0.764 & 0.855 & 0.753 \\
& $P G M 1^{*} 2$ & 0.235 & 0.145 & 0.231 \\
PGM3 & $P G M 1^{*} 7$ & - & - & 0.016 \\
& $P G M 3^{*} 1$ & 0.740 & 0.340 & 0.809 \\
ESD & $P G M 3^{*} 2$ & 0.260 & 0.660 & 0.191 \\
& $E S D^{*} 1$ & 0.881 & 0.913 & 0.628 \\
& $E S D^{*} 2$ & 0.100 & 0.085 & 0.364 \\
& $E S D^{*} 5$ & 0.019 & 0.002 & - \\
GPT1 & $E S D^{*} 7$ & - & - & 0.008 \\
& $G P T 1^{*} 1$ & 0.523 & 0.872 & 0.624 \\
6 GGD & $G P T 1^{*} 2$ & 0.474 & 0.128 & 0.376 \\
& $P G D^{*} A$ & 0.978 & 0.893 & 0.913 \\
ADA & $P G D^{*} C$ & 0.021 & 0.104 & 0.087 \\
& $A D A^{*} 1$ & 0.950 & 0.996 & 0.973 \\
& $A D A^{*} 2$ & 0.050 & 0.004 & 0.027 \\
\hline
\end{tabular}

で，真に蛋白質をコードする遺伝子座を代表するもの とは考えられない。

アロザイムは, 電気泳動上の移動度だけでなく, そ の活性, 安定性が互いに異なる場合が多い. ACP 1 の アロザイム A， B，Cの活性および安定性は $\mathrm{A}<\mathrm{B}<\mathrm{C}$ の順に高い6) (Fig.1). 6PGDのアロザイム A, Cの 活性の差は大きく無いが空定性は大きく異なって いる ${ }^{8}$. 一方, 日本人で多型を示す GOT1において, アロザイム 2 の活性は，アロザイム 1 の值の約 $50 \% に$ すぎない ${ }^{7)}$ が，安定性に差は無い8)。このような特質 を持つアロザイムを産生する対立遺伝子が，集団中に 高い頻度で保持される機構を説明するものとして, 自 然選択説と中立説がある. しかし，それらを解説する ことは本報の目的とするところでは無い.

現在知られている多型形質の中で，選択要因の明ら かなものは多くは無い. G6PDの多型現象は, マラリ アという環境要因による選択の結果と考えられるもの の一つである ${ }^{9}$. 黒人集団, 地中海沿岸および中東の集 団, 東南アジアの集団には, 抗マラリア剂のプリマキ

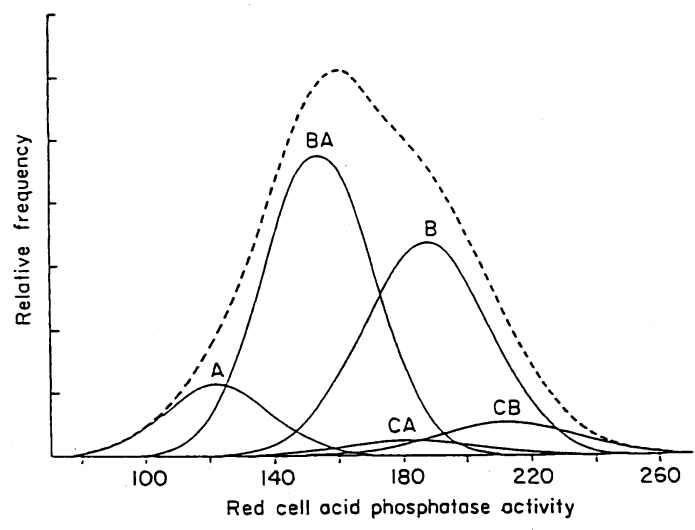

Fig. 1. Distribution of red cell acid phosphatase ( $\mathrm{ACP} 1)$ activities in the general population $(----)$ and in the separate phenotypes. (Hopkinson and Harris, 1969)

ン, サルファ剤その他の薬剤の投与や, ソラ豆の 1 種 （vicia fava）の摂取で, 重症の溶血性筫血を起こす 人々が存在する.これらの人々の G6PDは，黒人では 
$\mathrm{A}^{-}$，地中海沿岸地域（特に Sardinia）では $\mathrm{B}^{-}$（Mediterranean), 中国ではCanton, タイでは Mahidol と, 何れも活性の低い, 不安定な変異型である.これらア ロザイムの分布は，マラリアの流行する地域と一致し， (Fig. 2 ) また, HBS, HBE, $\beta$-サラセミア等の異常 へモグロビンの分布とも一致した ${ }^{10)}$.これら異常へモ グロビン, 特にHBSにおいては, マラリアによる選択 が詳しく研究されている. HBSを持つ赤血球は, マラ リア原虫（falciparum malaria）に対して抵抗性のあ ることが報告され ${ }^{11)}, \mathrm{G} 6 \mathrm{PD}$ に関しても同様な報告が ある ${ }^{12)}$.これらの知見に基づいて, 低活性 G6PD変異 型をコードする対立遺伝子は，マラリアによる選択の 結果, 多型の頻度に維持されてきたと理解されている。

赤血球酵素において, 酵素活性に対するスクリー二 ングが行われ, null対立遺伝子が多型の頻度で検出さ れた例としては，黒人集団の TPI* $Q O$ があり, 対立遺 伝子頻度 0.024 が報告されている ${ }^{13)}$.この対立遺伝子 に対してへテロ接合の黒人の赤血球卜リオース燐酸イ ソメラーゼ（TPI）の平均活性值は, 正常値の $57 \%$ で
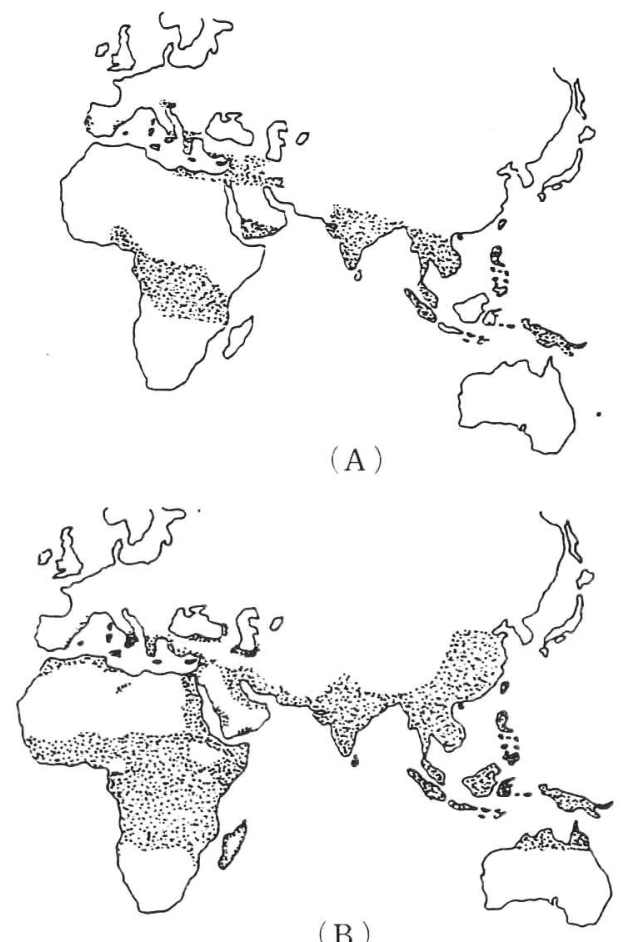

Fig. 2. World distribution of G6PD deficiency (A) and malignant malaria (B). (Man's Haemoglobins, Lehman and Huntsman, 1974)
あった．電気泳動パターンと熱安定性は正常型と変ら ず，TPI抗体と結合する蛋白質量は正常值の $1 / 2$ であ ったため, $T P I^{*} Q O$ 対立遺伝子を持つこれらのへテロ 接合の人々の TPI 遺伝子座においては, TPI 蛋白質の 合成が行われていないものと考之られる. 日本人集団 では, 炭酸脱水酵素 -19 null 対立遺伝子 $C A 1^{*} Q O$, ピルビン酸キナーゼ $(\mathrm{PK})$ の低活性変異型をコードす る対立遺伝子が, 多型とされる頻度よりは低いが, $0.004^{14)}$ および $0.007^{7)}$ の頻度で検出されている. TPI, $\mathrm{CA} 1, \mathrm{PK} の$ 何れにおいても, 電気泳動上の変異型の 頻度は非常に低いことと対照的である。

PGM1には，SGEで分離されるアロザイム 1 と 2 が あり，2 をコードする対立遺伝子 $P G M 1^{*} 2$ は, 調查さ れた全集団において多型の頻度を示した. $P G M 1^{*} 7$ は, 東南アジア, 南太平洋には多型の頻度で存在する ${ }^{15)}$. 日本人, 中国人，マレーシア土着人では， $0.01 \sim 0.03$ であるが，西カロライナ諸島では，0.06に達している (Fig. 3 ). また, $P G M 1^{*} 3$ の, パプアニューギニア, 西カロライ十諸島における頻度は 0.1 におよぶ ${ }^{15)}$. 沖 繩, 長崎, 広島でもPGM1 3 と非常によく似たアロザ

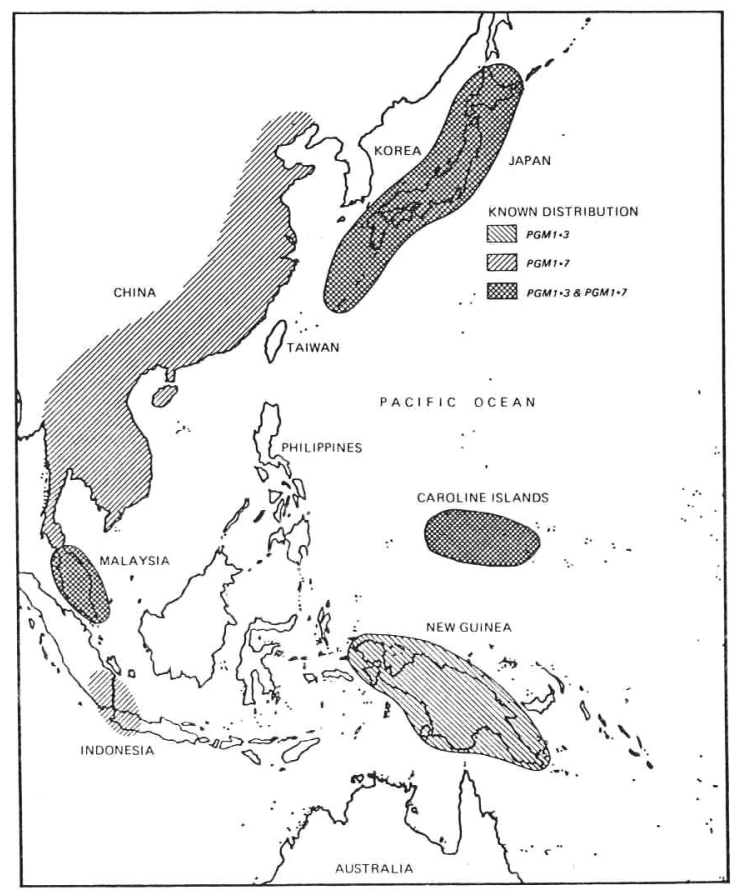

Fig.3. The known distributions of the $P{ }^{*}{ }^{*} 3$ and $P G M 1^{*} 7$ alleles in the Asia-Pacific area. (Takahashi et al. 1982) 
イムが検出され，沖繩の酵素は3OKINAWA，長崎， 広島の酵素は3NG1 と命名されているが，でんぷんゲ ル上での移動度は同一で，対立遺伝子頻度はそれぞれ $0.0039 ， 0.0022 ， 0.0009$ と，より南に位置する集団ほ ど高い ${ }^{16)}$. この $3 \mathrm{NG} 1$ は, 日本人の PGM1のまれな変 異型の中では最も頻度が高い. 有史以前の日本列島に はアイヌ人によく似た人々が広く居住していたが，琉 球，南西諸島からの集団の移動と，朝鮮半島からの集 団の移動によって，徐々に北方へと押しやられて行 ったと考えられていること，アイヌには $P G M 1^{*} 7$, $P G M 1^{*} 3$ は無く, 中国人集団にはP $P G M 1^{*} 3$ は検出さ れていないこと，Fig. 2 に見られる対立遺伝子の分布， さらに 3NG1，3OKINAWA の頻度を総合すると，南 方からの集団の移動の影響は, 日本の南西部においては 中央部におけるよりもほぼ3倍強いものと考えられる ${ }^{17)}$. PGM1には，このほかまれな変異型も多数報告されて おり SGE が唯一の検査法であった時代にも，変異の 多い多型性酵素であった。

酸性緩衝液を使う SGE，またはPAGIEF によって， PGM1 のアロザイム 1 が，1S と 1F または，1と１一， 2 が $2 \mathrm{~S}$ と $2 \mathrm{~F}$ または $2+$ と 2 -のサブタイプに分離され るようになり PGM1 の集団遺伝学におけるマーカーと しての重要性は更に増大した. 3 大人種の全てにおい て，このサブタイプの存在は確認され，それらが 4 種 の対立遺伝子 $P G M 1^{*} 1+, P G M 1^{*} 1-, P G M 1^{*} 2+$, PGM1*2-の産物であることが明らかとなった. (Table 2 ）これら対立遺伝子の頻度には, 人種による特徵が あるが，ロンドンのアジア人集団を除いて全ての集団
で $P G M 1^{*} 1$ +の頻度が最も高く, $P G M 1^{*} 2$-の頻度 が最も低かった ${ }^{18)}$.また，何れの集団でも，PGM1 ${ }^{*} 1+$ と $P G M 1^{*} 1$-の頻度の和は, $P G M 1^{*} 1$ の頻度と等し く, $P G M 1^{*} 2+$ と $P G M 1^{*} 2$-の頻度の和は, $P G M 1^{*} 2$ の頻度と等しかった。我々は, PAGIEFによって 7 を $7+$ と 7-，3を $3+$ と 3-のアロザイムに分離した (Fig. 4 ). 家族調査の結果から,これらは何れも異な る対立遺伝子の産物であることが明らかとなった ${ }^{17)}$.

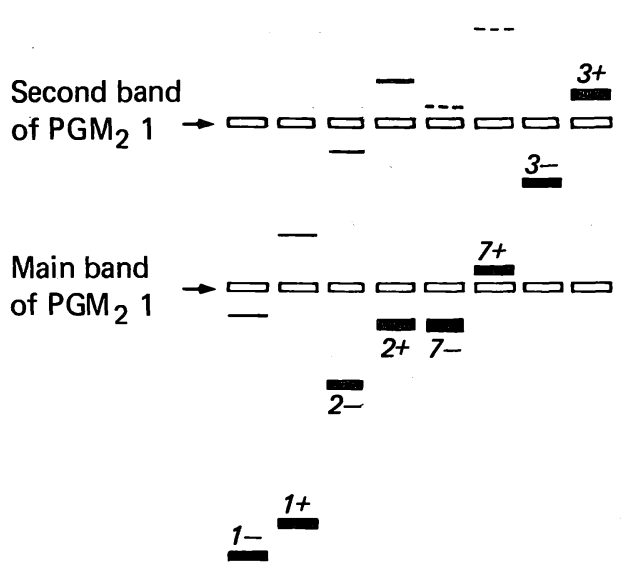

Fig. 4. Position of 8 allozyme bands of PGM1 after isoelectric focusing. (Takahashi et al. 1982)

Table 2. Frequencies of the PGM1 alleles determined by IEF.

\begin{tabular}{|c|c|c|c|c|c|c|c|c|}
\hline Population & $\mathrm{n}$ & $1+$ & $1-$ & $2+$ & $2-$ & $7+$ & $7-$ & Reference \\
\hline N. European & 2,773 & 0.627 & 0.132 & 0.182 & 0.058 & - & - & $\begin{array}{c}\text { Carter et al. } \\
\quad(1979)\end{array}$ \\
\hline \multicolumn{9}{|l|}{ Negroes } \\
\hline $\begin{array}{l}\text { Keneba } \\
\text { the Gambia }\end{array}$ & 637 & 0.795 & 0.053 & 0.133 & 0.019 & - & - & $\begin{array}{c}\text { Welch et al. } \\
(1978)\end{array}$ \\
\hline London & 384 & 0.672 & 0.126 & 0.173 & 0.027 & - & - & $\begin{array}{c}\text { Carter et al. } \\
\quad(1979)\end{array}$ \\
\hline \multicolumn{9}{|l|}{ Asian } \\
\hline Japan & 788 & 0.6758 & 0.1142 & 0.1434 & 0.0603 & 0.0057 & 0.0006 & $\begin{array}{l}\text { Takahashi et al. } \\
\text { (1982) }\end{array}$ \\
\hline London & 120 & 0.537 & 0.096 & 0.246 & 0.121 & - & - & $\begin{array}{c}\text { Carter et al. } \\
\text { (1979) }\end{array}$ \\
\hline
\end{tabular}


他の日本人集団に検出された 7 も $7+$ と 7 に分離さ れている．僅かな等電点の差を持ったアロザイムが, 少なくとも 4 組検出されたのだが，これらを作る対立 遺伝子は如何にして生まれたのであろうか？

$P G M 1^{*} 1+, P G M 1^{*} 1-, P G M 1^{*} 2+, P G M 1^{*} 2-$ の 4 種の対立遺伝子の生成に関して Carter らは,

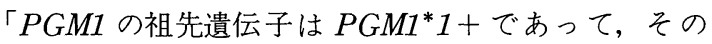
遺伝子にそれぞれ独立に 2 個の突然変異が生じて $P G M 1^{*} 2+$ と $P G M 1^{*} 1$ - が生成し, この二つの遺伝 子内交叉によって $P G M 1^{*} 2$-が生じた.」という仮説を 提出した ${ }^{18)}$.この仮説は次の事実に基づいている. (1) $\mathrm{SGE}$ とIEFによって，類人猿（チンパンジー，ゴリラ， オランウータン）の PGM1 を調べたところ, SGE では ヒトの 1 と, IEF ではヒトの $1+$ アイソザイムと移動 度の殆ど同じバンドが観察された(Fig. 5 ). (2) ヒトの 3 大人種において, 例外を除くと $P G M 1^{*} 1+$ の頻度が 最大, $P G M 1^{*} 2$-の頻度が最少. さらに(3)彼らの条件 で，アロザイム $1+$ と $2+$ との等電点の差は, 酸性側 に $0.18 \mathrm{pH}$ unitである. アロザイム $1+に ア ミ ノ$ 酸置 換が生じ, 酸性側に電荷 1 個分の変化を生じ $2+$ がで きたと考える. $1+$ と 1 -の等電点の差は, 塩基性側 に $0.05 \mathrm{pH}$ unit であり，1+に塩基性側に電荷が 1 個 分移るようなアミノ酸置換が生じて 1 -ができたと考 える. 第 3 のアロザイム $2-$ と $1+$ との等電点の差は 酸性側に 0.10 であるから，2+と 1 -の各々に生じた アミノ酸置換が, 同一蛋白質分子内に存在すると考之 ることができるというものであった. 2-をコードする 対立遺伝子 $P G M 1^{*} 2$-が, 第 3 の突然変異で生じたと 考えることも勿論できるが, 2 個の遺伝子の遺伝子内

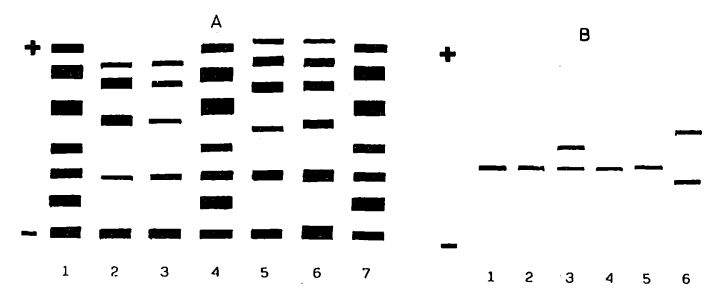

Fig. 5. Primate PGM phenotypes on starch gel electrophoresis and isoelectric focusing. (Carter et al. 1979)

A. Starch gel electrophoresis 1, 4, 7 : Human PGM1 1-2 2, 3 : Pongo $5,6:$ Gorilla

B. Isoelectric focusing 1,2: Gorilla 3: Human PGM1 $1^{+} 2^{-}$ 4, 5 : Pongo 6: Human PGM1 $1^{-} 2^{+}$

交叉によって新しい対立遺伝子が生じたと考えられる 事例は，ハプトグロビンの遺伝子等に関しては既に証 明されており, 遺伝子内交叉の起り得る可能性は十分 に考えられる。

我々は，Carter らの仮説を $7+, 7-, 3+, 3-を$ コードする対立遺伝子の生成にも導入することを試み た ${ }^{17)}$. Table 3 に, 我々の測定した 8 種のアロザイム の等電点を示す. (1) 4 組の（十）アロザイムと（一) アロザイムの等電点の差は, 何れも塩基性側に $0.1 \mathrm{pH}$ unit で, Carterが1-アロザイムに想定したアミノ酸置 換が共通に存在すると考えれば説明できる。(2) $1+$ と $7+の$ 等電点の差は酸性側に $0.3 \mathrm{pH}$ unit で, 電荷 1 個 の変化として考えられるが, $1+$ と $3+$ の差 $0.5 \mathrm{pH}$ unit

Table 3. The pI values of the products of the eight alleles at PGM1 locus.

\begin{tabular}{cccc}
\hline \hline $\begin{array}{c}\text { Isoelectric } \\
\text { type }\end{array}$ & pI value & $\begin{array}{c}\text { Isoelectric } \\
\text { type }\end{array}$ & pI value \\
\hline $1+$ & 6.3 & $1-$ & 6.4 \\
$2+$ & 6.1 & $2-$ & 6.2 \\
$7+$ & 6.0 & $7-$ & 6.1 \\
$3+$ & 5.8 & $3-$ & 5.9 \\
& & & \\
$1+-2+=0.2$ & Differences & & \\
$1+-7+=0.3$ & & $1--2-=0.2$ & \\
$1+-3+=0.5$ & & $1--7-=0.3$ & + \\
\end{tabular}


（酸性側）は少なくとも電荷 2 個分の変化である.し かし, 塩基性アミノ酸から酸性アミノ酸への 1 回の置 換による等電点の差は，へモグロビンで報告された例 ではもっと小さい值であり，アミノ酸置換が 2 ヶ所で 起ったものと考える方が妥当である. (3) Table 3 に見 られるように, $1+$ と $3+$ 差 $0.5 \mathrm{pH}$ unitは, $1+$ と $2+の$ 差 $0.2 \mathrm{pH}$ unitと, $1+と 7+の$ 差 $0.3 \mathrm{pH}$ unit の和となっている.（）アアアザイム相互間にも同様な 関係がある. $2+$ を生ぜしめたアミノ酸置換と，7+を 生ぜしめたアミノ酸置換が同一分子内に存在している ものが，3+アロザイムである．3ーアロザイムには， さらに 1 一を生ぜしめたアミノ酸置換ものっていること になる. 以上をまとめると,「祖先遺伝子 $P G M 1^{*} 1+$ に 独立に 3 回の突然変異が起って, 新しい 3 個の対立遺伝 子 $P G M 1^{*} 1$ - $P G M 1^{*} 2+, P G M 1^{*} 7+$ が生じる.こ れら合計 4 個の対立遺伝子間の遺伝子内交叉が 4 回起れ ば, $P G M 1^{*} 2-, P G M 1^{*} 7-, P G M 1^{*} 3+, P G M 1^{*} 3-$ が生じる.」という仮説で 8 個の対立遺伝子の誕生を 説明できる (Fig. 6 ).

これら 8 個の対立遺伝子のうち，1+，1-，2+， 2-をコードする対立遺伝子はどの人種にも高い頻度 で検出されるので, アジア一太平洋地域にのみ，低い 頻度で分布する $7+, 7-， 3+， 3-$ をードする対立 遺伝子よりも古いものと考えられる。それにつぐもの

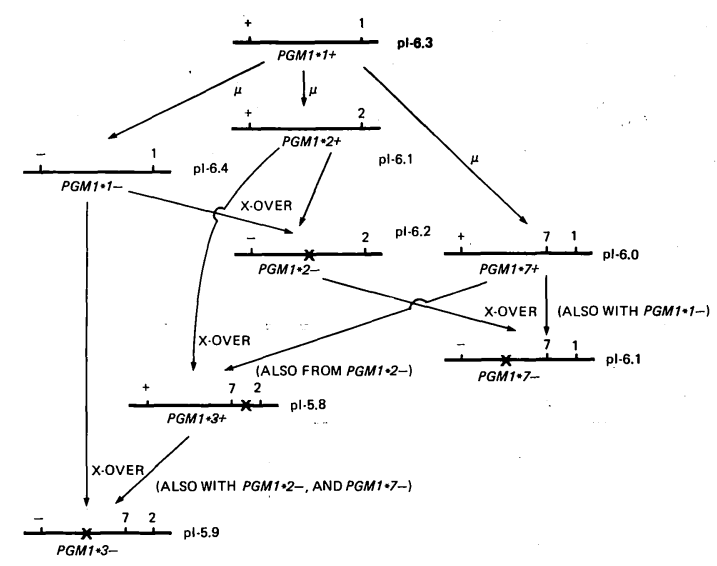

Fig.6. A proposed phylogeny relating eight alleles in the PGM1 system. The symbol $\mu$ indicates origin through mutation. The position of the postulated crossover is in each instance indicated by an $\mathrm{X}$. (Takahashi et al. 1982)
は，分布域の広さと頻度から $7+$ である可能性が高い． しかし, 頻度には選択と機会的変動の結果が入る可能 性がある. 一方, 想定された突然変異によって生じた 塩基置換の位置によって連鎖不平衡も変化すると考之 られる. 我々は, 将来 PGM1 遺伝子の DNA 配列が明 らかになった時, この仮説を検討できることを期待し ている.

この仮説によると，DNAの組み替えによって新し い対立遺伝子が作られるので，見かけ上の突然変異が 起ることになる. 例えば, $P G M 1^{*} 2+/ P G M 1^{*} 7+\infty$ 遺伝子型を持つへテロ接合の人の子供にアロザイム $3+$ が検出されると, 点突然変異の結果と考えられるであ ろう。この場合, 遺伝子内交叉によって生じた新しい 対立遺伝子 $P G M 1^{*} 3+$ は, Wわゆるハプロタイプであ るが, 電気泳動法で検查する限りは, 見かけ上, 点突 然変異となるのである.もし, 真の突然変異によって 生じた塩基置換が集団中に $\mathrm{n}$ 個固定されると, それら の間の交叉によって生成するものも含め, 対立遺伝子 数の合計は $2^{\mathrm{n}}$ となる. 真の突然変異の頻度にくらべ, 遺伝子内交叉の頻度は高いと考えられるので見かけ上 の突然変異率は高くなるだろう.

自然環境, 地理的特徵, 集団成立の歴史などの類似 した日本人とイギリス人の PGM1 を比較すると，日 本人の PGM1 では, 対立遺伝子の数もそれらの頻度 も高い. 一方, 姉妹遺伝子と考えられている PGM2に おいて，日本人の変異は非常にまれである．日本とイ ギリスにおいて，特別な選択要因の存在は考えられな いためPGM1 の多様性の差は, 突然変異率の差と考 えざるを得なかった ${ }^{19)}$. 前述の仮説に従えば，日本人 には多型に近い頻度で存在する $P G M 1^{*} 7+$ が見かけ上 の突然変異率の上昇に寄与している可能性がある. 日 本人の PGM2 には, それに相当する対立遺伝子が存 在しないため新しい対立遺伝子の生成の機会が無かっ たと考えられる.

PGM1 遺伝子座内には，このようにSGE で分離さ れる多型性を示すサイトと, IEF で分離される多型性 を示すサイトがあるのだが，このほかにSGEで分離さ れるサイトと強い連鎖不平衡を示し, 熱安定性を支配 するサイトの存在が報告されている ${ }^{20)}$. また, Nigeria の集団においては，G6PDの活性を支配し, 電気泳動 では分離されない隠された多型性のサイトの存在する 可能性が報告されている ${ }^{21)}$.このような構造遺伝子内 の “multisite intragenic polymorphism”の有無は, 
将来，遺伝子内 DNA の塩基配列の分析によって明ら かにされるであろう。

\section{交献}

1) Ford, E. B. : In The New Systematics, Ed. J.C. Huxley, Oxford Univ. Press, Oxford, 1940.

2) Smithies, O. : Biochem. J., 61:629, 1955.

3) Smithies, O. and Walker, N. F. : Nature, $176: 1265,1955$.

4) Beckman, G. : Enzyme polymorphism, in The Biochemical Genetics of Man, 2nd ed., Eds. D. J. H. Brock and O. Mayo, Academic Press, London, New York, San Francisco. 1978, 185-269.

5) Nei, M. and Roychoudhury, A. K. : Am. J. Hum. Genet., $26:$ 421, 1974.

6) Hopkinson, D. A. and Harris, H. : In Biochemical Methods in Red Cell Genetics, Ed. J. J. Yunis, Academic Press, New York, London, 1969, 337-375.

7) Satoh, C. et al. : Am. J. Hum. Genet., $35: 656,1983$.

8) Satoh, C. et al. : Ann. Hum. Genet., in press.

9) Livingstone, F. B.: Ann. Rev. Genet., 5 : 33, 1971
10) Lehmann, H. and Huntsman, R. G. : In Man's Haemoglobins. 2nd ed. North-Holland Publishing Co., Amsterdam, Oxford, 1974.

11) Pasvol, G. et al. : Nature, $274: 701,1978$.

12) Luzzatto, L. et al. : Science, $164: 839$, 1969.

13) Mohrenweiser, H. W. and Fielek, S. : Pediatr. Res., 16:960, 1982.

14) Goriki, K. and Hazama, R. : In Proceedings of Current Status of the Biology and Chemistry of Carbonic Anhydrase, 1983.

15) Blake, N. M. and Omoto, K. : Ann. Hum. Genet., 38, 251, 1975.

16) Satoh, C. et al. : Jpn. J. Hum. Genet., in press.

17) Takahashi, N. et al. : Proc. Natl. Acad. Sci., $79: 6636,1982$.

18) Carter, N. D. et al. : Ann. Hum. Biol., 6 : 221, 1979.

19) Neel, J. V. et al. : Ann. Hum. Genet., 41 : 429, 1978.

20) Scozzari, R. et al. : Ann. Hum. Genet., 45:313, 1981.

21) Modiano, G. et al. : Proc. Natl. Acad. Sci., $76:$ 852, 1979. 